\section{Enamel Subsurface Caries-Like Lesions Induced in Human Teeth By Different Solutions: A TMR Analysis}

Daiana Back Gouvêa ${ }^{1} \mathbb{B}$, Nicole Marchioro dos Santos $^{1} \mathbb{B}$, Juliano Pelim

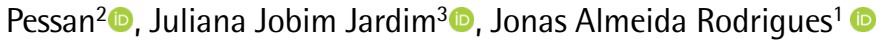

'Pediatric Dentistry Division, UFRGS

- Universidade Federal do Rio Grande do Sul, Porto Alegre, RS, Brazil ${ }^{2}$ Department of Preventive and Restorative Dentistry, UNESP - Univ Estadual Paulista, Aracatuba, SP, Brazil ${ }^{3}$ Cariology Division, UFRGS Universidade Federal do Rio Grande do Sul, Porto Alegre, RS, Brazil

Correspondence: Daiana Back Gouvea, Ramiro Barcelos, 2492, Porto Alegre, RS, Brazil. Tel: +55-51-33085018. e-mail: daiana.gouvea@ufrgs.br

Key Words: dental caries, remineralization, demineralization, $\mathrm{pH}$ cycling, TMR.
This study assessed the effectiveness of models for developing subsurface caries lesions in vitro and verified mineral changes by transverse microradiography (TMR). Enamel blocks from permanent $(n=5)$ and deciduous teeth $(n=5)$ were submitted to lesion induction by immersion in demineralizing solutions during $96 \mathrm{~h}$, followed by $\mathrm{pH}$ cycles of demineralization (de) and remineralization (re) for 10 days. Two de-/re solutions were tested. Demineralizing solution " $\mathrm{A}$ " was composed by $2.2 \mathrm{mM} \mathrm{CaCl}, 2.2 \mathrm{mM} \mathrm{KH}_{2} \mathrm{PO}_{4}$, $0.05 \mathrm{M}$ acetic acid, with $\mathrm{pH} 4.4$ adjusted by $1 \mathrm{M} \mathrm{KOH}$. Demineralizing solution "B" was composed by $2.2 \mathrm{mM} \mathrm{CaCl}_{2}, 2.2 \mathrm{mM} \mathrm{NaH}{ }_{2} \mathrm{PO}_{4}, 0.05 \mathrm{M}^{2}$ acetic acid and $0.25 \mathrm{ppmF}$, with $\mathrm{pH} 4.5$ adjusted by $1 \mathrm{M} \mathrm{KOH}$. Solution " $\mathrm{A}$ " produced cavitated lesions in permanent teeth, whereas solution "B" led to subsurface lesions in deciduous teeth. Solution "B" was then tested in enamel blocks from permanent teeth $(n=5)$ and subsurface lesions were obtained, so that solution " $\mathrm{B}$ " was employed for both substrates, and the blocks were treated with slurries of a fluoride dentifrice (1450 ppm $F$, as $N a F, n=5)$ or a fluoride-free dentifrice $(n=5)$. Solution "B" produced subsurface lesions in permanent and primary teeth of an average $( \pm$ SD) depth of $88.4 \mu \mathrm{m}( \pm 14.3)$ and $89.3 \mu \mathrm{m}( \pm 15.8)$, respectively. TMR analysis demonstrated that lesions treated with fluoride-free dentifrice had significantly greater mineral loss. This study concluded that solution "B" developed subsurface lesions after $\mathrm{pH}$ cycling, and that mineral changes were successfully assessed by TMR.

\section{Introduction}

Models based on $\mathrm{pH}$ cycling to mimic acid challenges occurring in the oral environment have provided comprehensive knowledge on the onset and progression of dental caries as well as the development of preventive and therapeutic methods $(1,2)$. Several methodologies to develop artificial caries lesions have been described to induce lesions with distinct characteristics. A relevant aspect in the choice of a caries-induction model is related to the formation of a subsurface lesion, which is observed in natural non-cavitated caries lesions, but is not artificially mimicked by many of the $\mathrm{pH}$-cycling models, resulting in induction of surface-softened lesions - also called erosionlike lesions (3).

Concerning the methods used to assess mineral loss in in vitro studies, transversal microradiography (TMR) is considered the gold standard (3). This technique can provide data on lesion depth, thickness of the surface layer, integrated mineral loss $(\Delta \mathrm{Z})$ and mineral loss according to lesion depth (R). Transverse microhardness is another method that, by means of calculations, can estimate the mineral loss of an artificial lesion. This methodology, however, evaluates various physical properties from those evaluated with TMR (4) as it detects the resilience of dental tissue, which is altered by mineral loss and gain (4). Among the several protocols to induce caries-like lesions in human enamel, two similar models have been tested using different de-/re-mineralizing solutions in permanent (5) and deciduous (6) enamel, employing TMR to quantify enamel mineral changes. These protocols seem to be easily achievable and present a favorable cost-benefit relationship considering de- and re-mineralization solutions. Such solutions, however, have been assessed in a limited number of studies.

Considering the need to establish protocols in which the same methodology could be used for both deciduous and permanent enamel, the aim of this study were to evaluate the effectiveness of the aforementioned $\mathrm{pH}$ cycling protocols in developing subsurface lesions in permanent and deciduous human enamel, as well as to demonstrate mineral changes in subsurface lesions after the use of a fluoridated dentifrice (1450 ppm F as NaF) verified by transverse microradiography (TMR). The null hypotheses tested in this study were that (1) the test solutions would produce similar subsurface lesions in primary and permanent enamel; and (2) no significant differences would be observed in mineral change of enamel treated with both dentifrices. 


\section{Material and Methods}

This study was approved by the University Local Ethics Committee (\#53508216.0.0000.5347).

For this two-step in vitro study, a total of 20 enamel blocks of permanent ( $4 \mathrm{~mm} \times 4 \mathrm{~mm}$ ) and 15 of deciduous teeth ( $3 \mathrm{~mm} \times 3 \mathrm{~mm}$ ) were obtained by sectioning using a diamond disc in metallographic cutter (Isomet 1000, Buehler Ltd., Lake Bluff, IL, USA), and their enamel surfaces were sequentially polished with 320,600, 1200, 2000 and 4000 grit sandpapers, felt disc with diamond paste 0 - 1 micra (Christensen Roder) and felt disc with diamond paste 0 - 1/2 micra (Christensen Roder).

Initial surface microhardness analysis was performed in order to allow the allocation of enamel blocks with no microhardness variation. A microhardness tester (Struers Duramin Microdurometer, Cotia, São Paulo, Brazil) was used, and 5 indentations spaced $100 \mu \mathrm{m}$ apart were made at the center of enamel surface, using Knoop indenter under $25 \mathrm{~g}$ load for $10 \mathrm{~s}$ (7). Samples of permanent enamel exhibited an average $( \pm$ SD) surface microhardness of $378.5( \pm 41.2)$ and samples of deciduous enamel of $360.0( \pm 24.8) \mathrm{KHN}$.

\section{Step 1: Development of Subsurface Lesions and TMR} Profile's Assessment

\section{Experimental Design}

Enamel blocks from permanent $(n=5)$ and deciduous $(n=5)$ teeth were used in this step. A third of each enamel block surface was covered by acid resistant nail polish and the blocks were immersed in individual vials containing $30 \mathrm{~mL}$ of each demineralizing solution during $96 \mathrm{~h}$ to develop initial artificial carious lesions. As suggested by the authors of previous studies $(5,6,8)$, demineralizing solution " $A$ " was used for permanent enamel blocks, and was composed by $2.2 \mathrm{mM} \mathrm{CaCl}_{2} 2.2 \mathrm{mM} \mathrm{KH}_{2} \mathrm{PO}_{4}, 0.05 \mathrm{M}$ acetic acid, with $\mathrm{pH} 4.4$ adjusted by $1 \mathrm{M} \mathrm{KOH}$. Similarly, demineralizing solution "B" was used for deciduous enamel blocks, and was composed by $2.2 \mathrm{mM} \mathrm{CaCl}_{2}, 2.2 \mathrm{mM} \mathrm{NaH}_{2} \mathrm{PO}_{4}, 0.05 \mathrm{M}$ acetic acid and $0.25 \mathrm{ppmF}$, with $\mathrm{pH} 4.5$ adjusted by $1 \mathrm{M} \mathrm{KOH}$. Solutions were prepared using deionized water, in recipients only used for this purpose.

Fresh demineralizing solutions with the same composition described above were later used for $\mathrm{pH}$ cycling. After this period of demineralization, samples had another third covered by acid resistant nail polish to preserve part of the initial lesion in order to observe differences in the characteristics between initial and progressed lesions. The blocks were then submitted to a $\mathrm{pH}$-cycling regimen during 10 days.

\section{Methods of $\mathrm{pH}$ Cycling}

The blocks were submitted to $\mathrm{pH}$ cycling for 10 days. Each $\mathrm{pH}$ cycle was comprised of $3 \mathrm{~h}$ of demineralization (twice a day), with a two-hour remineralization period in between, using an orbital shaker (Orbital Kline, CT 150, CIENTEC, Brazil). After each cycle, samples were immersed in a remineralizing solution overnight, without shaking. Fresh solutions were employed at each step, and the samples were immersed in individual vials with $30 \mathrm{~mL}$ of solution. Different solutions were utilized for permanent (solution "A") and deciduous enamel (solution "B"). Demineralizing solutions were prepared as previously described. Remineralizing solution " $\mathrm{A}$ " contained $1.5 \mathrm{mM}$ $\mathrm{CaCl}_{2}, 0.9 \mathrm{mM} \mathrm{NaH}_{2} \mathrm{PO}_{4}$ and $0.15 \mathrm{M} \mathrm{KCl}$, with $\mathrm{pH} 7.0$ adjusted with $1 \mathrm{M} \mathrm{KOH}(5,8)$, while remineralizing solution "B" contained $1.5 \mathrm{mM} \mathrm{CaCl}_{2}, 0.9 \mathrm{mM} \mathrm{NaH}_{2} \mathrm{PO}_{4}, 0.15 \mathrm{M} \mathrm{KCl}$ and 0.25 ppm F with a pH 7.0 adjusted with $1 \mathrm{M} \mathrm{KOH} \mathrm{(6).}$ After this step, the samples were analyzed by TMR to verify the subsurface characteristics. A summary of $\mathrm{pH}$-cycling regimens is described in Table 1.

\section{Transverse Microradiography (TMR) Analysis}

Blocks of permanent and deciduous teeth were transversely sectioned using a diamond disc in a metallographic cutter (Isomet 1000, Buehler Ltd., Lake Bluff, IL, USA), hand polished with 600 grit sandpapers and measured with digital caliper, until sections of an approximate thickness of $100 \mu \mathrm{m}$ were obtained. The samples were fixed in a plastic sample-holder with an aluminum calibration step wedge featuring 11 steps. Microradiography was carried out with an x-ray generator (Softex, Tokyo, Japan) on a glass plate at $20 \mathrm{kV}$ and $20 \mathrm{~mA}$ for $20 \mathrm{~min}$ at a distance of $42 \mathrm{~cm}$. The glass plate was developed for $5 \mathrm{~min}$, rinsed in deionized water, fixed for $3 \mathrm{~min}$ in a dark room, and then rinsed in running water for $10 \mathrm{~min}$ followed by air drying. The plate was evaluated with a transmitted light microscope fitted with a 20x objective (Axioplan; Zeiss, Oberkochen, Germany), a CCD camera (XC-77CE; Sony, Tokyo, Japan) and a computer. Two photographs per specimen were captured using data
Table 1 . Summary of solutions and regimens tested.

\begin{tabular}{lccccccccc}
\hline Regimen & \multicolumn{2}{c}{ Demineralization } & \multicolumn{4}{c}{ Remineralization } & \multicolumn{3}{c}{ Demineralization } \\
\hline & $\begin{array}{c}\text { time, } \\
\mathrm{h}\end{array}$ & $\begin{array}{c}{[\mathrm{F}],} \\
\mathrm{ppm}\end{array}$ & $\mathrm{pH}$ & $\begin{array}{c}\text { time, } \\
\mathrm{h}\end{array}$ & $\begin{array}{c}{[\mathrm{F}],} \\
\mathrm{ppm}\end{array}$ & $\mathrm{pH}$ & $\begin{array}{c}\text { time, } \\
\mathrm{h}\end{array}$ & $\begin{array}{c}{[\mathrm{F}],} \\
\mathrm{ppm}\end{array}$ & $\mathrm{pH}$ \\
\hline $\mathrm{A}$ & 3 & 0.00 & 4.4 & 2 & 0.00 & 7 & 3 & 0.00 & 4.4 \\
$\mathrm{~B}$ & 3 & 0.25 & 4.5 & 2 & 0.25 & 7 & 3 & 0.25 & 4.5 \\
\hline
\end{tabular}

Demineralization A: $2.2 \mathrm{mM} \mathrm{CaCl}_{2}, 2.2 \mathrm{mM} \mathrm{KH}_{2} \mathrm{PO}_{4}, 0.05 \mathrm{M}$ acetic acid, with $\mathrm{pH} 4.4$ adjusted by $1 \mathrm{M} \mathrm{KOH}$. Remineralization A: $1.5 \mathrm{mM} \mathrm{CaCl}_{2}, 0.9 \mathrm{mM} \mathrm{NaH}_{2} \mathrm{PO}_{4}$ and $0.15 \mathrm{M} \mathrm{KCl}$, with pH 7 adjusted through $1 \mathrm{M} \mathrm{KOH}$. Demineralization B: $2.2 \mathrm{mM} \mathrm{CaCl}_{2}, 2.2 \mathrm{mM} \mathrm{NaH}_{2} \mathrm{PO}, 0.05 \mathrm{M}^{2}$ acetic acid and $0.25 \mathrm{ppmF}$, with $\mathrm{pH} 4.5$ adjusted by $1 \mathrm{M} \mathrm{KOH}$. Remineralization $\mathrm{B}: 1.5 \mathrm{mM} \mathrm{CaCl}_{2}, 0.9$ $\mathrm{mM} \mathrm{NaH2PO4,} 0.15 \mathrm{M} \mathrm{KCl}$ and $0.25 \mathrm{ppm} \mathrm{F}$ with a $\mathrm{pH} 7$ adjustment by $1 \mathrm{M} \mathrm{KOH}$ 
acquisition (TMR 1.25e; Inspektor Research BV, Amsterdam, The Netherlands) of initial and progressed lesions, and their surface characteristics were qualitatively analyzed through calculation software (TMR 1.25e; Inspektor Research BV, Amsterdam, The Netherlands) (9). Macroscopical analysis indicated that blocks from permanent teeth exhibited enamel surface cavitation. Therefore, solutions "B" were applied to additional permanent enamel blocks $(n=5)$ as described for deciduous teeth and step 1 was repeated for this sample.

\section{Step 2: Mineral Changes in Subsurface Lesions \\ Experimental Design}

In this step, other set of enamel blocks from permanent $(n=10)$ and deciduous $(n=10)$ teeth were used. These blocks were randomly divided into two treatment groups ( $n=5$ for permanent and deciduous enamel): fluoride-free dentifrice (Curaprox Enzycal Zero - Curaden International, Switzerland) and fluoride-containing dentifrice with $1450 \mathrm{ppm} \mathrm{F}$ as $\mathrm{NaF}$ (Curaprox Enzycal 1450 - Curaden International, Switzerland). The randomization was performed from a list of random numbers generated on "randomizer.org". A third of the enamel surface of each block was covered by acid resistant nail polish and the blocks were immersed in the demineralizing solution "B" during the course of $96 \mathrm{~h}$ to induce initial artificial carious subsurface lesions. Afterwards, the samples had another third covered by acid resistant nail polish to preserve part of the initial lesion in order to compare the mineral loss between the progressed and initial lesions. The blocks were submitted to a pH-cycling regimen for 10 days, using demineralizing and remineralizing solutions " $B$ " and a treatment with slurry of each dentifrice for 60 seconds, twice a day, at the beginning and at the end of each day. Slurries were composed of dentifrices and deionized water in the proportion of $1 / 3$. Subsequently, integrated mineral loss was measured by TMR.

\section{Transverse Microradiography (TMR)}

\section{Analysis}

The preparation of specimens and acquisition of TMR images were performed as described in step 1. The mineral content was calculated assuming the density of the mineral to be $3.15 \mathrm{~kg} \mathrm{l}^{-1}$ and $87 \mathrm{vol} \%$ of mineral content for the sound enamel (9). The integrated mineral loss $(\Delta \mathrm{Z})$ was calculated for the initial and progressed lesions. Treatments were then compared by calculating differences between $\Delta$ Zprogression and $\Delta$ Zinitial.

\section{Statistical Analysis}

Statistical analysis was performed with SPSS 20.0 software (SPSS Inc., Chicago, IL, USA) assuming a significance level of $5 \%$. Variables were tested for normality and homoscedasticity by KolmogorovSmirnov and Levene's tests, respectively. Groups were compared through independent samples t-test and paired samples t-test.

\section{Results}

\section{Step 1: Subsurface Lesion Development}

Solution "A" was not able to induce subsurface lesions in enamel blocks of permanent teeth, and cavitation of the specimens was observed. However, solution "B" led to initial subsurface lesions in deciduous enamel, as observed by TMR. Subsequently, after $\mathrm{pH}$ cycling of permanent teeth using solution "B", induction of initial subsurface lesions was also successfully found with TMR.

\section{Step 2: Subsurface Characteristics, Depth and Mineral Distribution $(R)$}

Solution "B" induced initial subsurface lesions of an average $( \pm$ SD) depth of $88.4 \mu \mathrm{m}( \pm 14.3)$ and $89.3 \mu \mathrm{m}( \pm$ 15.8), respectively for permanent and deciduous enamel blocks ( $p=0.898$ ). The depth of the initial lesions between groups of fluoride concentrations was not different for deciduous teeth ( $p=0.833)$. For fluoride treated permanent teeth the depth of initial lesions was statistically higher $(p=0.024)$ than those treated without fluoride. After $\mathrm{pH}-$ cycling, the lesions kept the subsurface pattern, and the average depth was $136.4 \mu \mathrm{m}( \pm 29.9)$ and $136.7 \mu \mathrm{m}( \pm 35.6)$, respectively. Data concerning average lesion depth is presented in Table 2. For both permanent $(p=0.034)$ and deciduous samples $(p=0.042)$, treatment with fluoridated or non-fluoridated dentifrices promoted significant differences regarding the progression of lesion depth after pH cycling (Table 2). Groups treated with the fluoride-free dentifrice presented lesion depth significantly greater
Table 2. Depth of initial and progressed lesion for deciduous and permanent teeth after treatments assessed by TMR

\begin{tabular}{|c|c|c|c|}
\hline \multirow[b]{2}{*}{ Group } & \multicolumn{2}{|c|}{ Mean lesion depth $\left(\mu m_{ \pm} \mathrm{SD}\right)$} & \multirow{2}{*}{$\begin{array}{c}\text { Mean depth } \\
\text { increasing }\left(\mu \mathrm{m}_{ \pm} \mathrm{SD}\right)\end{array}$} \\
\hline & $\begin{array}{c}\text { Initial lesion } \\
\quad(96 \mathrm{~h})\end{array}$ & $\begin{array}{c}\text { Progressed } \\
\text { lesion (10 days) }\end{array}$ & \\
\hline Permanent & $88.4(14.3)^{* * * *}$ & & \\
\hline Permanent 0 ppm F & $78.9(7.5)^{+}$ & $152.2(22.5)^{+}$ & $73.3(17.4)^{*}$ \\
\hline Permanent 1450 ppm F & $97.9(13.3)^{\S}$ & $120.5(29.6)^{\S}$ & $22.6(40.9)^{*}$ \\
\hline Deciduous & $89.3(15.8)^{* * * *}$ & & \\
\hline Deciduous 0 ppm F & $90.6(3.6)^{\ddagger}$ & $166.1(35.9)^{\ddagger}$ & $75.5(39.0)^{* * *}$ \\
\hline Deciduous 1450 ppm F & $88.3(22.1)^{\uparrow}$ & $113.1(2.6)^{\uparrow}$ & $21.9(9.7)^{* * *}$ \\
\hline
\end{tabular}

*Independent samples t-test $(\mathrm{p}=0.034) .{ }^{* *}$ Independence samples t-test $(\mathrm{p}=0.042)$. ****Independent samples t-test $(\mathrm{p}=0.898)$. + Paired samples T Test $(\mathrm{p}=0.001)$. $\neq$ Paired samples T Test $(p=0.030)$. \$Paired samples T Test $(p=0.284)$. $\{$ Paired samples T Test $(p=0.064)$. 
than groups treated with the fluoride dentifrice (Table 2). Subsurface patterns of lesions are depicted in Figures 1 and 2, respectively, for permanent and deciduous enamel, showing laminations formed through the lesion during the $\mathrm{pH}$ cycling process. Figures 3 and 4 demonstrate examples of TMR graphs of lesion depth and mineral loss in permanent and deciduous human enamel, respectively.

Regarding the mineral distribution of the lesion, expressed by $\mathrm{R}$ values ( $\Delta \mathrm{Z} / \mathrm{l}$ lesion depth), permanent teeth showed an average R-value of $37.4( \pm$ SD 5.7) and deciduous of $30.1( \pm S D$ 11.8). Note that these are considered high R-values (10).

\section{Integrated Mineral Loss $(\Delta Z)$}

Data for the average integrated mineral loss is presented in Table 3 . Regarding the difference between $\Delta$ Zinitial and $\Delta$ Zprogression, groups treated

Table 3. Integrated mineral loss for deciduous and permanent teeth after treatments assessed by TMR

\begin{tabular}{lccc}
\hline \multirow{2}{*}{ Group } & \multicolumn{2}{c}{$\Delta \mathrm{Z}$} & \multicolumn{1}{c}{$\Delta$ Zinitial - } \\
\cline { 2 - 3 } & $\begin{array}{c}\text { Initial lesion } \\
(96 \mathrm{~h})\end{array}$ & $\begin{array}{c}\text { Progressed } \\
\text { lesion (10 days) }\end{array}$ & $\Delta$ Zprogression \\
\hline Permanent & $3311(737.3)^{* * * *}$ & & \\
Permanent 0 ppm F & $2710(504.5)^{\dagger}$ & $5706(694.2)^{\dagger}$ & $-2996(490.7)^{*}$ \\
Permanent 1450 ppm F & $3912(256.7)^{\S}$ & $4172(1413.3)^{\S}$ & $-260(1383.7)^{*}$ \\
Deciduous & $2690(1162.4)^{* * * *}$ & & \\
Deciduous 0 ppm F & $3375(1469.2)^{\ddagger}$ & $6685(1584.9)^{\ddagger}$ & $-3310(682.4)^{* * *}$ \\
Deciduous 1450 ppm F & $2142(488.7)^{\Uparrow}$ & $2126(671.2)^{\Uparrow}$ & $16(410.5)^{* * *}$ \\
\hline
\end{tabular}

*Independent samples t-test $(\mathrm{p}=0.009) .{ }^{* *}$ Independent samples t-test $(\mathrm{p}=0.000)$. ****Independent samples t-test $(\mathrm{p}=0.178)$. + Paired samples T Test $(\mathrm{p}=0.000)$. $\neq$ Paired samples T Test $(p=0.002)$. \$Paired samples T Test $(p=0.696)$. \Paired samples T Test $(p=0.935)$.
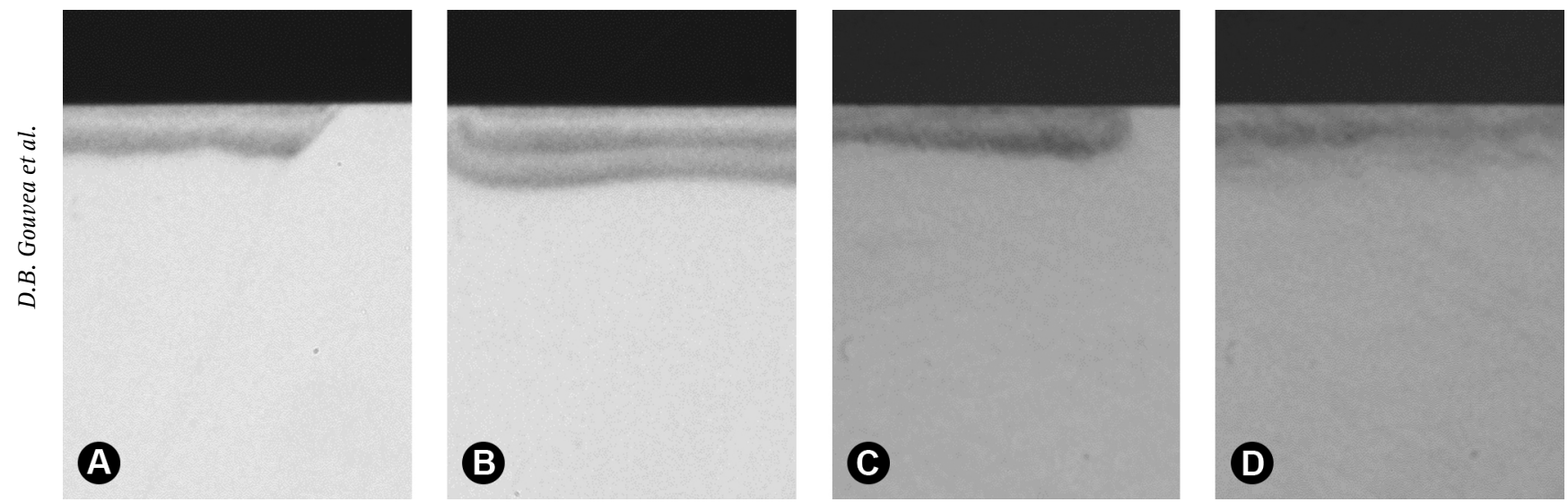

Figure 1. Subsurface lesions in permanent human enamel samples. A: Initial caries lesion in permanent enamel. B: Sample observed in image "a" after 10 days of pH-cycling and treatment with non-fluoridated dentifrice. C: Initial caries lesion in permanent enamel. D: Sample observed in image "c" after 10 days of pH-cycling and treatment with fluoridated dentifrice.
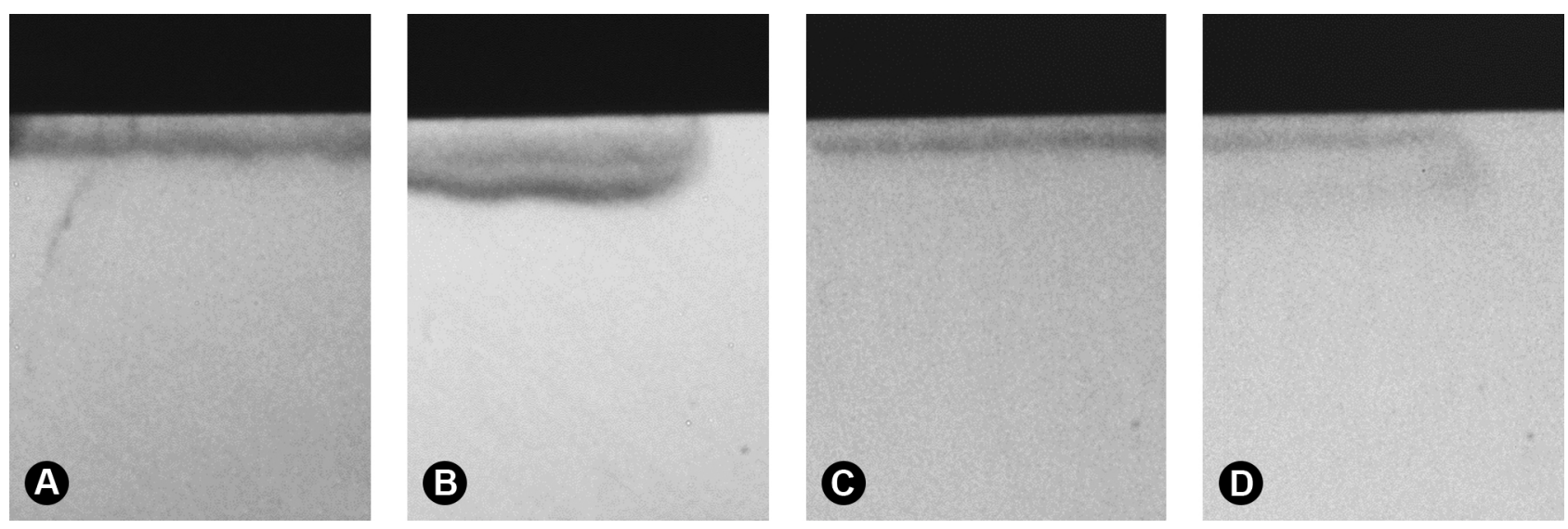

Figure 2. Subsurface lesions in deciduous human enamel samples. A: Initial caries lesion in deciduous enamel. B: Sample observed in image "a" after 10 days of $\mathrm{pH}$-cycling and treatment with non-fluoridated dentifrice. C: Initial caries lesion in deciduous enamel. D: Sample observed in image "c" after 10 days of $\mathrm{pH}$-cycling and treatment with fluoridated dentifrice. 
with $1450 \mathrm{ppm} F$ had lower integrated mineral loss, for both permanent $(p=0.009)$ and deciduous enamel $(p<0.001)$. Groups treated with the fluoride-free dentifrice demonstrated a significant increase in mineral loss.

\section{Discussion}

This study tested two different solutions protocols for the induction of artificial caries lesions. While solution " $\mathrm{A}$ " induced cavitation of the surface, solution " $B$ " induced subsurface lesions with high R-values, and was shown to be an adequate method to test mineral loss. Both methodologies $(5,6)$ were chosen to be tested following the suggestion of previous usage of TMR for mineral content evaluation.

Earlier studies have shown positive results after solution "A" was employed to assess the efficacy of fluoridated products $(6,8)$. In the present experiment, however, rupture of the surface was observed. The absence of fluoride in the $\mathrm{pH}$-cycling model solutions is a matter that interferes with this dissolution, and models that apply demineralizing
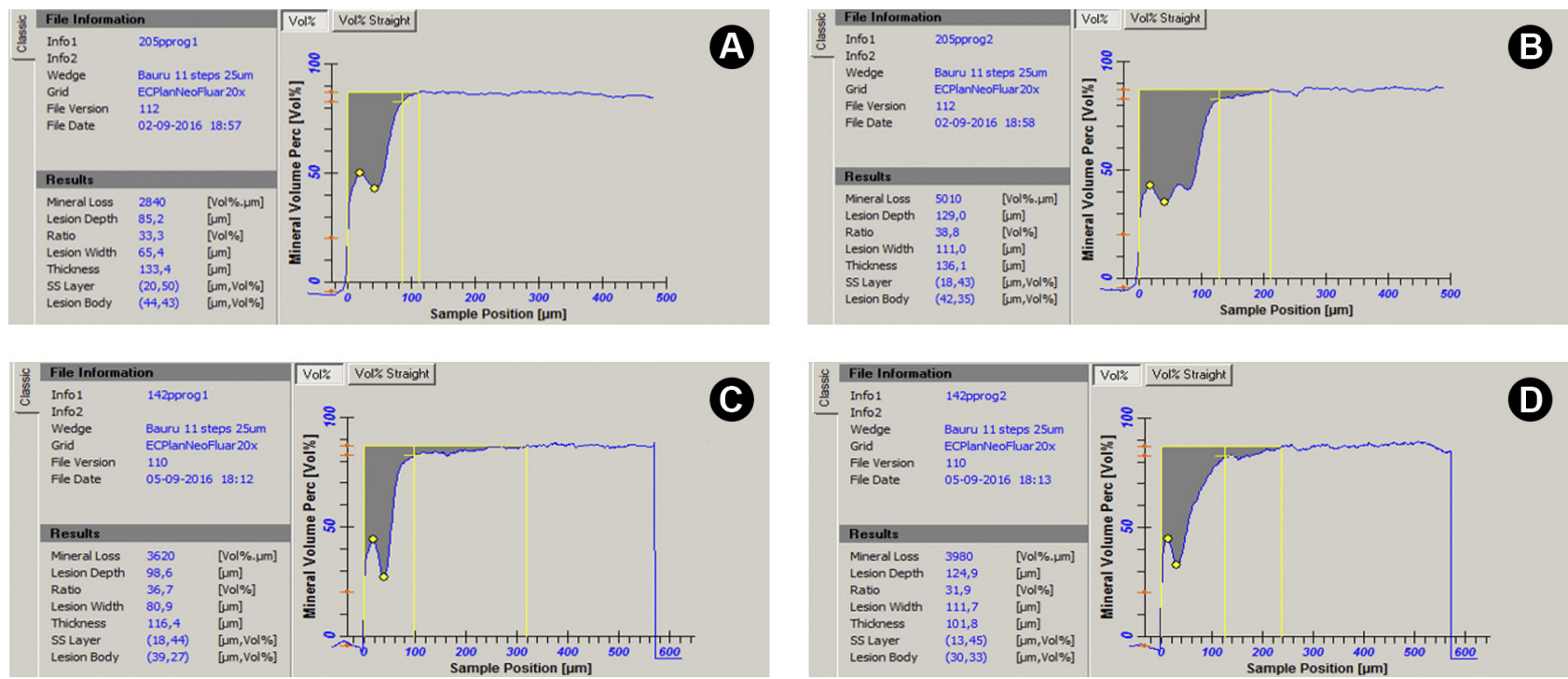

Figure 3. TMR graphs of lesion depth and mineral loss of permanent human enamel. A: Initial lesion in permanent human enamel. B: Sample observed in "A", with progressed lesion after 10 days of pH-cycling and treatment with non-fluoridated dentifrice. C: Initial lesion in permanent human enamel. D: Sample observed in "C", with progressed lesion after 10 days of pH-cycling and treatment with fluoridated dentifrice.
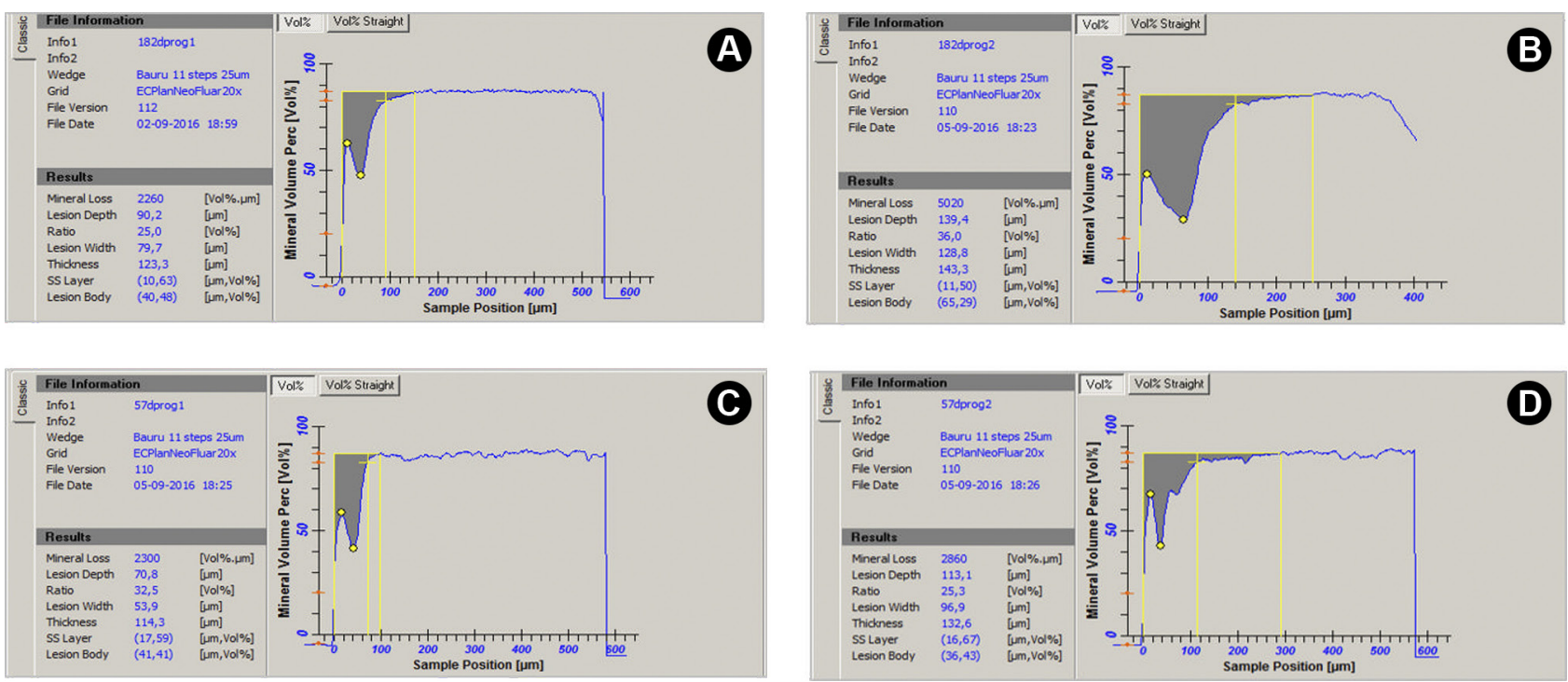

Figure 4. TMR graphs of lesion depth and mineral loss of deciduous human enamel. A: Initial lesion in deciduous human enamel. B: Lesion observed in "A", with progressed lesion after 10 days of pH-cycling and treatment with non-fluoridated dentifrice. C: Initial lesion in deciduous human enamel. D: Lesion observed in "C", with progressed lesion after 10 days of pH-cycling and treatment with fluoridated dentifrice. 
and remineralizing solutions containing fluoride should, therefore, be preferable $(3,11,12)$. Caries model using solution "B", suggested by Thaveesangpanich et al. (6), is a modification of a previous model (13) that is not recommended for deciduous enamel during a period longer than seven days because surface dissolution can be observed (14). The modification of this model consisted of the addition of $0.25 \mathrm{ppm} F$ in both demineralizing and remineralizing solutions to permit a $\mathrm{pH}$-cycling experimental period of 10 days (6). Presence of fluoride in $\mathrm{pH}$-cycling solutions is already known to influence the extent of the experimental period (15). The increase in experimental duration is desirable because one of the highlighted limitations of in vitro studies related to dental caries is the greater speed of establishment of artificial caries lesions when compared with the natural process.

Owing to the satisfactory results achieved using solution "B" in deciduous enamel, this solution was then applied for permanent enamel. The idea of applying a method that makes use of a fluoride-containing solution seemed appropriate because of the positive influence of the fluoride content of solutions on the preservation of the lesion surface. This fact has already been reported (11, $\vec{s}$ 12). Moreover, the usefulness of the same caries model in permanent and deciduous enamel facilitates comparison of the results and makes it easier to standardize the experiment. The method using solution " $\mathrm{B}$ " is adequate to compare treatments in deciduous and permanent human enamel, since it induces initial lesions with similar depth $(p=0.898)$ and mineral loss $(p=0.178)$ in both substrates as observed in Tables 1 and 2.

Initial lesions of fluoride treated permanent enamel were deeper than those treated without fluoride. It is important to state that this difference did not compromise the results of the study, since the treated blocks showed a lower progression rate even when they had deeper lesions. Besides, this difference between the depth of initial lesions was only possible to be detected after TMR analysis.

Solution "B" led to the development of subsurface lesions, with a lamination pattern, with high R-values in both permanent and deciduous enamel. As already reported in literature, the lamination pattern is developed due to alternating des/remineralization episodes in presence of fluoride which is absorbed in varying concentrations in different lesion depths (16). Lesions with high R-values were reported to be suitable for assessing the differences between treatments as they were more responsive to disparities between remineralizing solutions (10). A nonfluoridated dentifrice and a dentifrice with 1450 ppm $F$ were chosen because the efficacy of dentifrices with this latter fluoride concentration in inhibiting demineralization and inducing remineralization is well-described in the literature $(17,18)$ and the inability of demonstrate such a difference would contraindicate this $\mathrm{pH}$-cycling model for caries evaluation by TMR. The use of this pH-cycling model, however, was compatible with TMR to evaluate mineral loss because groups treated with fluoridated dentifrice presented reduced mineral loss compared to those treated without fluoride $(p<0.05)$.

\section{Resumo}

Este estudo avaliou a efetividade de modelos para o desenvolvimento de lesões de cárie subsuperficiais in vitro e verificou alterações minerais por microradiografia transversal (TMR). Blocos de esmalte de dentes permanentes $(n=5)$ e decíduos $(n=5)$ foram submetidos à indução de lesão por imersão em soluções desmineralizadoras durante 96 h, seguido de ciclos de $\mathrm{pH}$ de desmineralização e remineralização por 10 dias. Duas soluções des-/re foram testadas. A solução desmineralizadora " $\mathrm{A}$ " foi composta por 2,2 $\mathrm{mM}$ de $\mathrm{CaCl}_{2}$ 2,2 mM de KH2P04, 0,05 M de ácido acético, com $\mathrm{pH}$ de 4,4 ajustado por $1 \mathrm{M}$ de $\mathrm{KOH}$. A solução desmineralizadora "B" foi composta por 2,2 $\mathrm{mM}$ de $\mathrm{CaCl}_{2}, 2,2 \mathrm{mM}$ de $\mathrm{NaH}_{2} \mathrm{PO}_{4}, 0,05 \mathrm{M}$ de ácido acético e 0,25 ppmF, com pH de 4,5 ajustado por $1 \mathrm{M}$ de $\mathrm{KOH}$. A solução "A" produziu lesões cavitadas em dentes permanentes, enquanto a solução "B" apresentou lesões subsuperficiais em dentes decíduos. Portanto, a solução "B" foi posteriormente usada em blocos de esmalte de dentes permanentes $(n=5)$ e lesões subsuperficiais foram obtidas. Portanto, a solução "B" foi empregada para ambos os substratos, sendo metade deles tratada com dentifrício fluoretado e a outra metade com dentifrício livre de flúor. A solução "B" produziu lesões subsuperficiais de cárie com profundidade de $88.4 \mu \mathrm{m}$ (14.3) em dentes permanentes e com $89.3 \mu \mathrm{m}$ (15.8) em dentes deciduos e TMR demonstrou que lesões tratadas com dentifrício sem flúor tiveram maior perda mineral. Este estudo concluiu que a solução "B" desenvolveu lesões subsuperficiais após o ciclo de $\mathrm{pH}$ e as alterações minerais foram avaliadas com sucesso por TMR.

\section{References}

1. ten Cate JM. Models and Role Models. Caries Res 2015;49:3-10.

2. White DJ. The application of in vitro models to research on demiralization and re-mineralization of the teeth. Adv Dent Res 1995;9:175-193.

3. Buzalaf MA, Hannas $A R$, Magalhães $A C$, Rios $D$, Honório HM, Delbem AC. $\mathrm{pH}$-cycling models for in vitro evaluation of the efficacy of fluoridated dentifrices for caries control: strengths and limitations. J Appl Oral Sci 2010;18:316-334.

4. Featherstone JD, ten Cate JM, Shariati M, Arends J. Compari-son of artificial caries-like lesions by quantitative microradiography and micro-hardness profiles. Caries Res 1983;17:385-391.

5. Kumar VLN, Itthagarun A, King NM. The effect of casein phosphopeptide amor-phous calcium phosphate on remineralization of artificial carieslike lesions: an in vitro study. Austr Dent J 2008;53:34-40.

6. Thaveesangpanich $P$, Itthagarun A, King NM, Wefel JS. The effects of child formu-la toothpastes on enamel caries using two in vitro $\mathrm{pH}-$ cycling models. Inter Dent J 2005;55:217-223.

7. Favretto CO, Danelon $M$, Castilho FC, Vieira $A E$, Delbem $A C$. In vitro evaluation of the effect of mouth rinse with trimetaphosphateon enamel demineralization. car-ies Res 2013;47:532-8.

8. Rana R, Itthagarun A, King NM. Effects of dentifrices on artificial caries like le-sions: an in vitro Ph cycling study. Inter Dent J 2007;57:243-248.

9. Salomão PM, Comar LP, Buzalaf MA, Magalhães AC. In situ remineralisation re-sponse of different artificial caries-like enamel lesions to home-care and profes-sional fluoride treatments. BMC Oral Health. 2016;16:1-9.

10. Lynch RJM, Mony U, ten Cate JM. Effect of lesion characteristics and mineralis-ing solution type on enamel remineralisation in vitro. Caries Res 2007;41:257-262.

11. Larsen JM. Chemically induced in vitro lesions in dental enamel. Scand 
J Dent Res 1974;82:496-509.

12. Theuns HM, van Dijk JW, Driessens FC, Groeneveld A. The influence of the com-position of demineralizing buffers on the surface layers of artificial carious lesions. Caries Res 1984;18:509-518.

13. Itthagarun A, Wei SHY, Wefel JS. The effect of different commercial dentifrices on enamel lesion progression: an in vitro $\mathrm{pH}$-cycling study. Inter Dent J 2000;50:21-28.

14. Thaveesangpanich $P$, Itthagarun A, King NM, Wefel JS, Tay FR. In vitro model for evaluating the effect of child formula toothpastes on artificial caries in primary dentition enamel. Am J Dent 2005;18:212-6.

15. Gibbs CD, Atherton SE, Huntington E, Lynch RJ, Duckworth RM. Effect of low levels of fluoride on calcium uptake by demineralized human enamel. Arch Oral Biol 1995;40:879-881.

16. Vieira AEM, Danelon M, Camara DM, Rosselli ER, Stock SR, Cannon ML, et al. In vitro effect of amorphous calcium phosphate paste applied for extend periods of time on enamel remineralization. J Appl Oral Sci 2017;25:596-603.

17. Marinho VC, Higgins JP, Sheiham A, Logan S. Fluoride toothpastes for prevent-ing dental caries in children and adolescents. Cochrane Database Syst Rev 2003;1.

18. Twetman $\mathrm{S}$, Axelsson $\mathrm{S}$, Dahlgren $\mathrm{H}$, Holm AK, Källestål $\mathrm{C}$, Lagerlöf $\mathrm{F}$, et al. Caries-preventive effect of fluoride toothpaste: a systematic review. Acta Odontol Scand 2003;61:347-355.

Received August 24, 2019 Accepted November 20, 2019 